Article

\title{
Multiparametric Analysis of Urban Environmental Quality for Estimating Neighborhood Renewal Alternatives
}

\author{
Dalit Shach-Pinsly ${ }^{1, *}$, Stefan Bindreiter ${ }^{2}$, Idan Porat ${ }^{1}$, Shai Sussman ${ }^{1}$, Julia Forster ${ }^{2}$ \\ and Michael Rinnerthaler ${ }^{2}$ \\ ${ }^{1}$ Faculty of Architecture and Town Planning, Technion-Israel Institute of Technology, Israel; \\ E-Mails: dalitsp@technion.ac.il (D.S.-P.), idanpo@technion.ac.il (I.P.), shaisu@technion.ac.il (S.S.) \\ 2 Institute of Spatial Planning, Technical University of Vienna, Austria; E-Mails: stefan.bindreiter@tuwien.ac.at (S.B.), \\ julia.forster@tuwien.ac.at (J.F.), michael.rinnerthaler@tuwien.ac.at (M.R.) \\ * Corresponding author
}

Submitted: 26 April 2021 | Accepted: 21 July 2021 | Published: 17 November 2021

\begin{abstract}
The neighborhood renewal process is an important opportunity to update the built environment; however, major changes to the built environment might decrease spatial performance and environmental quality. In these processes, there is a need to evaluate urban renewal alternatives, especially the quality of the environment, to understand the performance of the newly designed built environment. The quality of the built environment depends on a variety of aspects (such as walkability, energy level, security, open spaces, water permeability, etc.), several of which can be assessed using diverse measurements and evaluation models. Current new technological developments, based on GIS, enable the evaluation of diverse aspects of environmental quality and promote urban renewal decision-making processes. Urban renewal needs to harness these models in the decision-making approaches to improve assessment processes of urban renewal alternative estimations that consider future performance and quality of the built environment. In this article, we present a 3D-GIS multiparametric scenario analysis for neighborhood renewal alternatives estimation to evaluate the performance and quality of the built environment as part of the decision-making process. The multiparametric approach will include an evaluation analysis of several aspects of environmental quality, including walkability, accessibility, sense of security, energy, shade, water infiltration, visibility, and more. The analysis results will indicate the level of performance for each aspect as indices for environmental quality. The multiparametric scenario analysis for neighborhood renewal will be conducted on three renewal alternatives for one neighborhood in the city of Hatzor HaGlilit, Israel.
\end{abstract}

\section{Keywords}

3D-GIS; design alternative evaluation; Hatzor HaGlilit; neighborhood renewal; parametric analysis; urban environmental quality

Issue

This article is part of the issue "Towards Digital Urban Regeneration: Embedding Digital Technologies Into Urban Renewal Processes and Development" edited by Dalit Shach-Pinsly (Technion-Israel Institute of Technology, Israel).

(C) 2021 by the authors; licensee Cogitatio (Lisbon, Portugal). This article is licensed under a Creative Commons Attribution 4.0 International License (CC BY).

\section{Introduction}

Neighborhood regeneration processes are often difficult to promote in peripheral areas due to diverse aspects such as populations having a low socioeconomic status, economic factors (contractors' and entrepreneurial profits), low density, and more (Healey, 1995). However, many towns and cities located in peripheral areas experience population growth and aspire for urban regeneration of old city neighborhoods to be improved and updated. Therefore, there is a need to develop high-quality urban regeneration processes; moreover, there is a need to evaluate the performance and environmental quality of the newly developed neighborhood alternatives. 
Over the last few decades, the quality and performance of the environment have become fundamental in urban planning and design (Carmona \& Sieh, 2004; Cicerchia, 1996; Shach-Pinsly, 2010), aiming to evaluate and measure diverse aspects of environmental quality, such as security (Shach-Pinsly, 2019), visibility (Ortner et al., 2016), walkability (Leslie et al., 2007), and energy (Forster, 2016). Therefore, urban renewal decision-making processes must consider the environmental quality of the renewal area according to a variety of quality aspects and develop a multiparametric scenario analysis approach to understand the quality of the neighborhood to be built. In peripheral areas, it is particularly valuable to understand the urban performance of renewed areas, which is influenced by diverse environmental qualities. Therefore, in this research, we use a parametric analysis approach of multiple environmental qualities for understanding the outcome performance of the renewed urban environment.

Perry's "neighborhood unit" theory (Mumford, 1954; Perry, 2007) presented an important concept for the design of districts/neighborhoods within a city. The concept was an early diagrammatic planning model for organizing new residential communities as functional, selfcontained neighborhoods in the early 20th century in industrializing cities. Questions relating to environmental quality were laid out as a fundamental basis; however, they were related more to safety and usage separation to provide better air quality for the residents.

\subsection{Multiparametric Analysis, Decision-Making Processes, and Urban Renewal}

Recent planning discourse has been characterized by concepts and approaches that emphasize aspects of sustainability, resilience, and compatibility. Often, these concepts build on previous ideas (e.g., Howard's garden city) and turn away from outdated principles (e.g., car-friendly city). Current concepts focus on a high building density and mixed land use so as to avoid urban sprawl and long distances for the provision of public services (e.g., education, work, shopping), as well as to ensure more efficient use of (energy) resources. Newer concepts additionally address other sustainability aspects, such as local material and energy flows, nature conservation, mobility reduction through mixeduse, and qualified densities to provide inhabitants with a better quality of life (Bibri et al., 2020; Cervero \& Kockelman, 1997; Gaffron et al., 2005).

The scenario technique is a proven method for mapping and describing possible future developments against the background of different planning cases, trends, and framework conditions. This technique is well known in spatial planning; for example, scenarios have been used in urban and spatial planning in the fields of land development (Waddel, 2002), sustainable urban development, mobility research (Mitteregger et al., 2019), and technology impact assessment (Duinker
\& Greig, 2007). They are considered an established means of identifying development horizons (sometimes participatory) for cities and regions (e.g., scenario processes in Munich, Hamburg, Zurich, or Vienna in recent years). However, the innovation is the performance evaluation process. Although the planning scenarios aim to understand the spatial layout of the urban renewal outcomes, the performance and quality of the environment are hidden and invisible through this process. This usually occurs due to several reasons: lack of models and tools for measuring the quality of the environment, lack of understanding regarding which parameters influence diverse aspects of the quality of the built environment that affect the urban performance, and lack of models for integrating the performance analysis results into the urban regeneration process.

This research aimed to create a planning and decision-making process for neighborhood renewal based on multiparametric analysis that considers the environment quality and performance of the renewed area. The main objective was to determine parameters for evaluation based on (a) known parameters that influence the quality and performance of the environment, (b) available data, and (c) previous knowledge of analysis methods and tools. We reviewed diverse parameters and selected parameters that met these criteria, including parameters that relate to basic indicators such as building footprint, roof area, and green space, as well as performance indicators such as energy consumption, public transport, shaded area, solar potential, sense of security, walkability, and visibility.

This article will focus on the "boot" neighborhood in Hatzor HaGlilit and present three urban renewal alternatives for this neighborhood. Hatzor HaGlilit is located in the northern part of Israel. The town was founded in 1952 and housed immigrants mainly from North Africa. The "boot" neighborhood is characterized by middle-class mass housing, built in the 1950s and 1960s. In 2019, Hatzor HaGlilit had a population of 9,300, mainly religious-traditional Jewish.

\section{Literature Review}

Current urban regeneration strategies relate mainly to improving buildings, infilling new buildings within existing urban construction, demolishing old buildings, constructing new buildings, and integrating diverse communities into deteriorated locations (Carmon, 2001; Kleinhans, 2004). Different strategies for physical urban regeneration developed around the world show a diversity of models. For example, in the US, most urban renewal focuses on demolishing large-scale mass housing projects and transforming them into small-scale housing projects for mixed-income residents (Goetz, 2010). An urban renewal policy in England, the New Deal Communities, aims to renovate and improve existing public residences. Austria developed mixed-use areas with affordable housing known as "soft urban renewal" 
(Huber, 2011). Porat and Shach-Pinsly (2019) aimed to improve urban renewal processes based on identifying post-World War II mass housing suitable for urban renewal. This model assists in improving top-down urban renewal processes with a wide view of the potential for mass housing stock to be renewed.

Middle-class mass housing projects were developed around the world and in Israel to settle refugee residents after World War II (Shadar, 2009). Currently, a large portion of these housing buildings are old (50-70 years old) and do not meet current construction requirements (such as building materials, small apartment sizes, infrastructure systems, etc.); thus, many of these neighborhoods need to go through a process of urban renewal to provide higher quality for residents (Carmon, 1998). Physical urban regeneration is one of the main aspirations of city regeneration (Jeffry \& Pounder, 2016); however, there is a lack of knowledge regarding the quality and performance of the renewed area (Carmona, 2019).

Most middle-class mass housing in Israel is developed based on the "international style," with similar methods and tools to those used for development in Europe (Shadar et al., 2011). The "international style" building typology includes block housing with clear, straight geometrical lines and flat roofs, as developed in Hatzor HaGlilit. Because of low budgets, the buildings' quality was reduced, resulting in poor physical condition of apartments for residents from low socioeconomic situations (Shadar et al., 2011).

Current urban regeneration in Israel focuses on three main strategies: (a) condensation by adding singlebedroom apartments to buildings to increase land efficiency, (b) demolishing and redeveloping construction by increasing building rights, and (c) strengthening buildings against earthquakes using the newly developed General Master Plan No. 38 (Planning Director, 2005) by adding two to three apartment floors to existing buildings or by demolishing and redeveloping new buildings with increased building rights.

Much of the urban renewal research on mass housing is based on sociological analysis to identify specific urban sites (Apparicio et al., 2008). The urban regeneration strategy relates mainly to individual buildings at a site and to social aspects and does not consider the performance of the developed site. Currently, there is a shift toward new challenges of mass housing regeneration for policymakers and decision-makers, as well as growing involvement of the public sector for large-scale neighborhood urban renewal projects (Cunningham \& Sawyer, 2005; Porat \& Shach-Pinsly, 2019). Methods and tools for evaluating neighborhoods' environmental quality have been further developed and spread since the beginning of the 21st century. There is a need to understand the quality of the built environment due to its influence on the deterioration of public space (Carmona \& Sieh, 2004); however, currently, there is no comprehensive evaluation process for the physical master plans (Waldner, 2004). Carmona and Sieh (2004) and Carmona and Magalhães (2007) developed a multi-quality analysis tool-positive-local-qualities-which summarizes a wide range of environmental dimensions that influence the quality of the environment, including the amount of planted green areas and foliage, security, accessibility, economic vitality, and more. Furthermore, Carmona (2019) measured the quality in public open spaces and the value of the built environment in relation to health, society, economy, and environment, using the "place quality" tool, aiming to expose the role of design in influencing the quality of the environment. Talen (1996) showed that the planning program and its implications are used in relation to a particular dimension, such as the functionality system that influences the planning appendices or planning instructions, etc. Forster (2016) defined visualizations as important tools in planning, as well as in estimating "impacts of planning measures before their realization" (Talen, 1996, p. 73). Shach-Pinsly and Porat (2016) evaluated the planning of master plans based on a place-based identity versus iterative top-down and bottom-up approaches. Walkability measures the ease of walking in a defined area. In addition, diverse researchers connect walkability with better health, and environmental and economic benefits (Florida, 2014). Several factors influence walkability, including quality of walking routes (sidewalks and footpaths), pedestrian rights-of-way such as good crosswalks, land use patterns, sense of safety, and security (Bain, et al., 2012). Furthermore, it is important for developing sustainable urban planning and design and improves quality of life (Shelton, 2008). Several models aimed at evaluating walkability, including that of Frank et al. (2010), who developed the walkability index for understanding quality of life. Leslie et al. (2007) developed a model for discovering environmental attributes relevant to the walkability of local communities. Shach-Pinsly (2019) developed the "security rating index" (SRI) for analyzing secure and unsecured urban areas to integrate these outcomes in the planning process. The concept of performance-based energy (or building) codes (Cruz \& Abreu, 2017; Foliente, 2000; Hui, 2002), or safety codes (Tavares, 2009) attempt to provide clear guidelines (e.g., energy or fire safety codes) for building development that takes into consideration the complexity of the building designs. In this sense, there is difficulty in understanding the complexity of the urban environment design. Furthermore, Shach-Pinsly and Capeluto (2020) introduced the concept of "performance-based codes" for understanding the role of performance in the planning process and how it can be integrated into the planning and design process. In this research, we introduce a new approach that associates the performance-based codes concept with evaluating different alternatives for the urban renewal process.

Over the last few decades, evaluation tools have been developed and mainly used to evaluate whether diverse buildings and neighborhoods have been successful as sustainable development goals (Sharifi \& 
Murayama, 2013). For example, LEED-ND promotes green neighborhoods that reduce vehicle miles, increase public transport, and include green building infrastructure by developing a rating system for design, construction, operation, and maintenance (Szibbo, 2015). BREEAM (UK) is a system for rating and evaluating a range of environmental issues such as ecology, health and well-being, and waste, among others, based on sustainability metrics and indices; it also focuses on neighborhood development (Sharifi \& Murayama, 2013). Neighborhood $360^{\circ}$ is a rating system tool that aims to promote quality, healthy, and livable development and design for better and more prosperous neighborhoods based on points given for the entire project (The Israeli Green Building Council, n.d.). The city resilience index (Fitzgibbons \& Mitchell, 2019) assesses cities to monitor and measure factors contributing to city resilience. However, these models are mainly rating-based methods and not planning-based ones. The analysis is performed on a large scale and does not go into the planning and program details. The overall score is characterized by categories so that the overall quality of the plan can be understood, but spatial/visual analysis of the quality of the environment is lacking.

Such complex issues are among the most important challenges in spatial planning. Schönwandt (1999) and Selle (1997) described the need for cooperative processes in which visualization and planning support tools are used. They serve as important communication tools to be able to prepare data for different target groups in a comprehensible way and to depict different professional perspectives on complex problems. Socially and genderrelevant aspects can also be considered, as D'Ignazio and Klein (2020) showed. Digital methods help to structure such complex problems, as well as their sub-aspects.

\section{Methodology}

\subsection{Methodology Framework}

The research aim was to develop a comprehensive evaluation process for urban regeneration decision-making based on quality and performance analysis of the developed area. The methodology is based on the integration of analysis knowledge for evaluating the quality and performance of the built environment developed by an international team from the GIS Lab, TechnionIsrael Institute of Technology, and the Simlab (Spatial Simulation Lab of Vienna University of Technology). The researchers aimed to demonstrate a comprehensive performance assessment of the "boot" neighborhood in Hatzor HaGlilit, Israel. The project area selection was based on former studies and research developed at a planning studio (Ulpan 2, 2019), which showed the need for further research and involved the proposal of explicit development paths and concrete instructions for action.

Three urban renewal alternatives were developed for the "boot" neighborhood: (a) preserving the cur- rent spatial design, (b) promoting the real-estate level of the neighborhood, and (c) promoting social and community performance. The alternatives analysis aimed to understand the quality and performance of each alternative by assessing 15 environmental quality parameters, including basic indicators-e.g., roof area (potential area for photovoltaic [PV]), green areas, and paved (public) roads-and performance indicators-e.g., public transport, shaded areas, walkability, and sense of security. The basic research assessed key aspects of the areae.g., current spatial and landscape features, cultural value, environmental and economic conditions, sociodemographic context, and regional/local policies for development of the area-followed by a quality and performance analysis of the urban regeneration alternatives for the area.

The flow of the research was as follows (see Figure 1):

a. Develop three urban renewal alternatives for the "boot" neighborhood;

b. Analyze each alternative according to the 15 environmental quality/performance criteria;

c. Obtain results of each quality/performance criterion for all three alternatives;

d. Urban regeneration decision-making based on multiparametric alternatives analysis;

e. This current research relates to the design of the urban environment from the point of view of the planner and the scale of a master plan, and not from the architectural scale. The main importance was to understand the possibility of adding layers of evaluation to the process of urban renewal for a better development decision-making process for a neighborhood. Therefore, the selection of indicators is adjusted to the neighborhood scale.

\subsection{The "Boot" Neighborhood in Hatzor HaGlilit}

Perry's "neighborhood unit" concept (Mumford, 1954; Perry, 2007) employs a variety of social and physical design principles, among them separation of vehicular and pedestrian traffic, arterial boundaries defining the inward neighborhood cell, neighborhood radius of a one-quarter mile, sizing the neighborhood to sufficiently support a school, and including between 5,000 to 9,000 residents.

The "boot" neighborhood is located in the southeastern part of Hatzor HaGlilit and is shaped like a boot, hence its name (see Figure 2). The area of the neighborhood is about 13 ha and is relatively flat and walkable. The housing density is six to 10 housing units per $1,000 \mathrm{~m}^{2}$. The city bus stops are located on the main axis of the neighborhood.

This is one of the first neighborhoods built in the city in the 1950s and includes residential buildings of a variety of types: private and semidetached houses adjacent to each other with relatively wide-open spaces between 


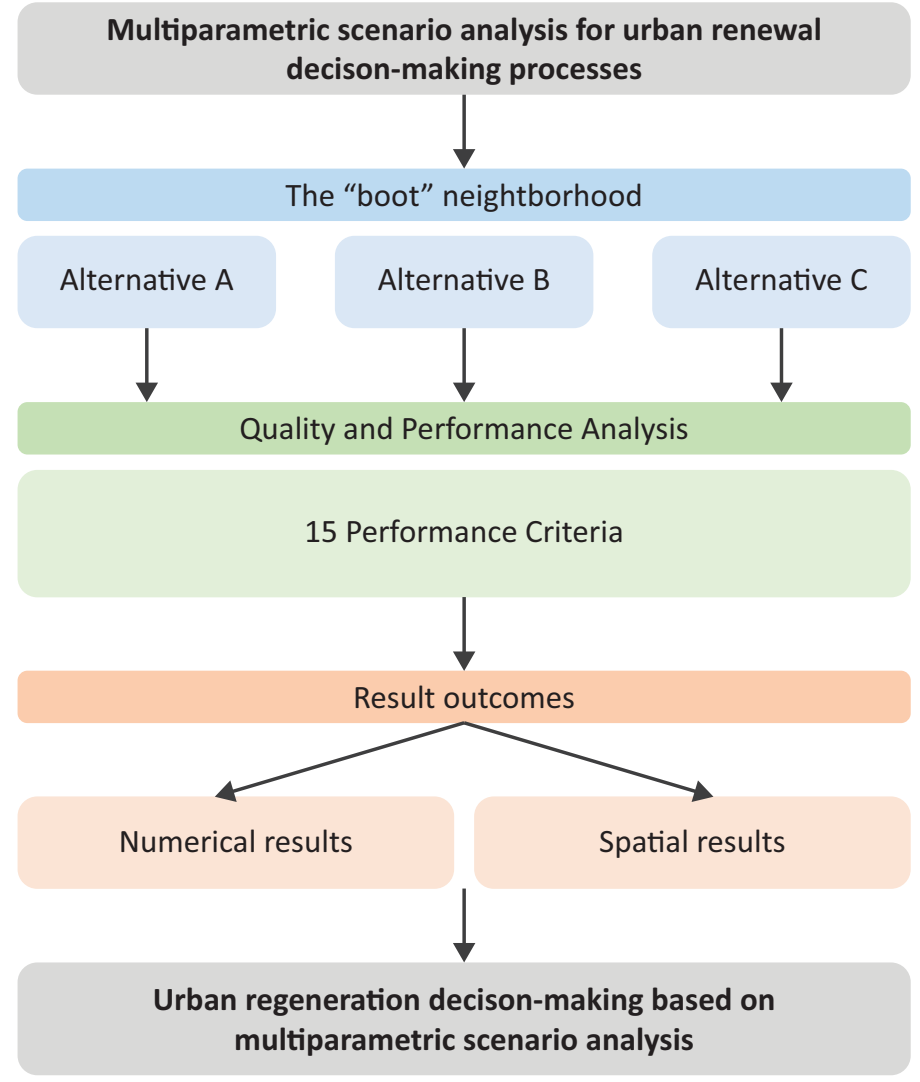

Figure 1. The research's flow.

them, three to four stories high public housing arranged in diverse layouts with wide patios between the buildings, $\mathrm{H}$-shaped buildings, and parking lots for some of the buildings. The distribution layouts of the building cre- ate the sense of a low-density area with vast open areas. The neighborhood contains a number of commercial and public buildings distributed in various locations and includes health care, a community center, community

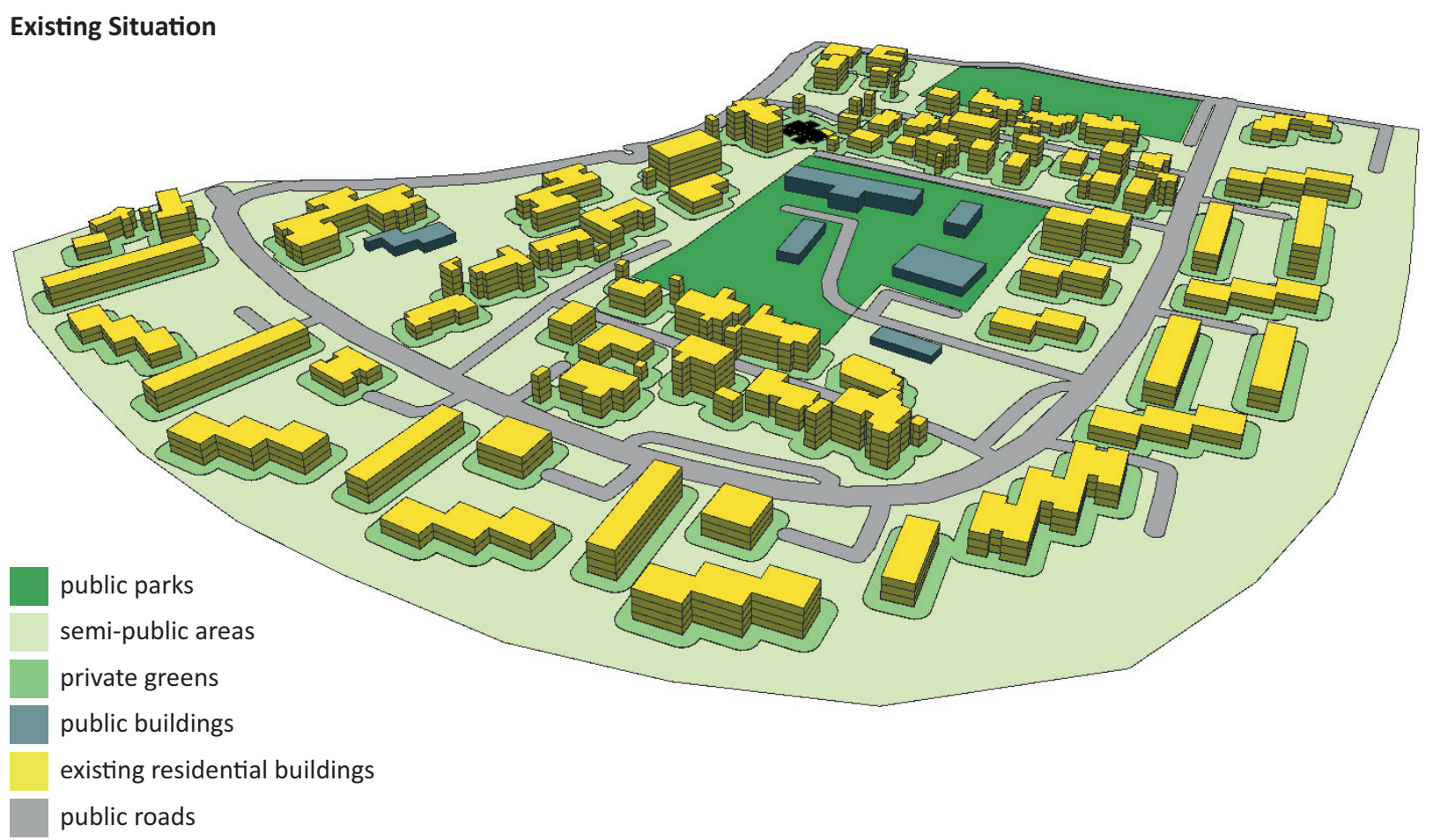

Figure 2. Current status of the "boot" neighborhood in Hatzor HaGlilit. 
police, a synagogue, a kindergarten and nursery, an elementary school, and a high school.

The neighborhood's population consists of immigrants from North Africa and Romania, mainly traditional-religious, who immigrated to the country in the 1950s and 1960s, as well as residents who immigrated from the Soviet Union during the 1990s. Today, the neighborhood has around 2,800 residents. The entire population lives in about 900 housing units (around 3.1 persons per household). Hatzor HaGlilit belongs to cluster four (out of 10) of the socioeconomic index. The unemployment rate is $6.8 \%$. The average wage is $23 \%$ lower than the state average and is around 8,000 ILS.

\subsection{Scenario Alternatives Development}

To understand the influence of urban renewal on a defined area, different themes/directions of urban renewal need to be developed. Therefore, we are introducing three urban renewal alternatives that represent the different themes/directions: (1) "the economic alternative," that strengthens real estate aspects based on defined compact and a repetitive urban typology for efficient land use development; (2) "a community alternative," an urban morphology that promotes community relations based on common public areas between buildings; and (3) "business as usual," preserving the existing structure with infill construction and the construction of additional floors. The differences between the urban alternatives are regarding the residential buildings' layout and types; none of the alternatives involves changes in the commercial/service/amenities buildings and main streets in the area.

\subsubsection{The Economic Alternative}

This alternative was developed based on superblock buildings, of between two and five floors, along the main road of the neighborhood. In the main area, there are single residential buildings, seven floors high, located around the public buildings and open spaces (see Figure 3).

\subsubsection{The Community Alternative}

Alternative 2, which promotes social and community performance, is structured by 21 compounds of residential buildings, each with two buildings: an L-shaped-fourto-five-floor building around a single seven-story building. These compounds lay on both sides of the main road and surround the commercial/service buildings and wide-open space in the central area of the neighborhood (see Figure 4). The article does not deal with the population; however, some studies show that physical characteristics contribute to community performance (Ewing \& Clemente, 2013; Papas et al., 2007). Therefore, we emphasize social performance based on measuring parameters that influence social and community performance, as internal visibility (eyes on the street for personal security), sense of security, walkability, and shade (very important for the community's performance in Israel's hot climate). These urban parameters are significant for social and community relations.

\section{Alternative 1}

superblocks 2 to 5 floors residential buildings with 7 floors

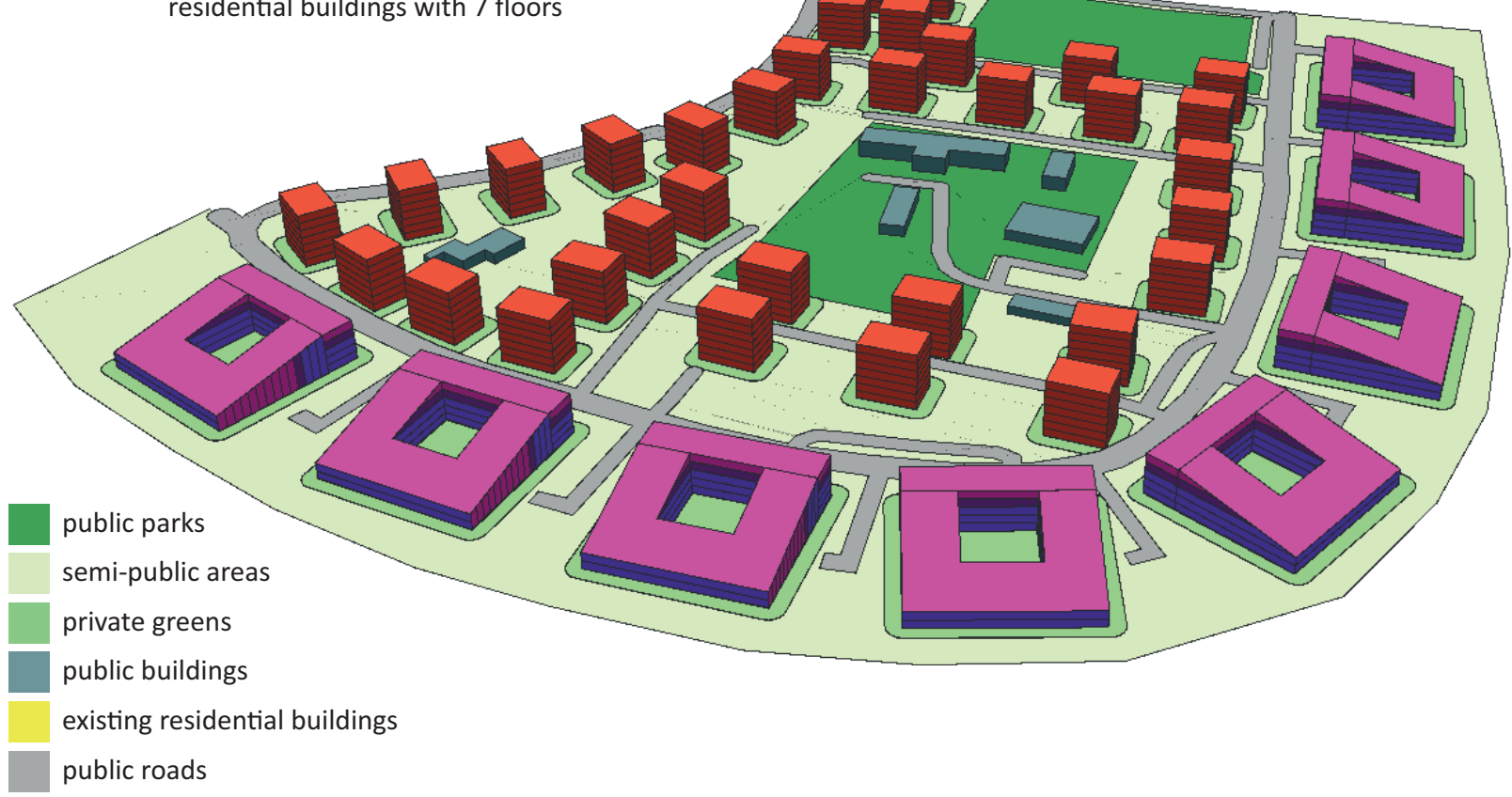

Figure 3. Alternative 1: "Economic alternative," promoting the real-estate level of the neighborhood. 


\section{COGITATIO}

\section{Alternative 2}

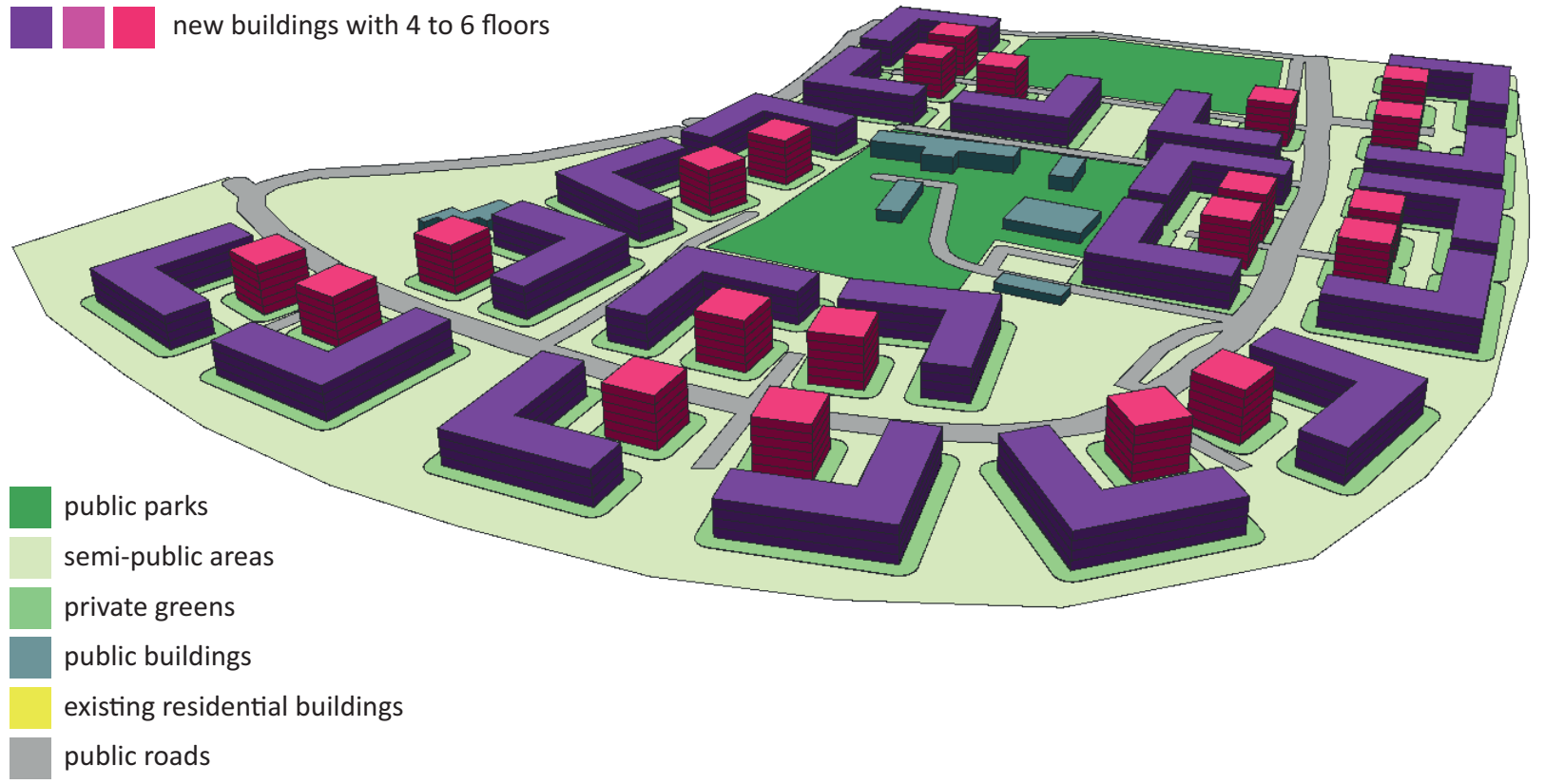

Figure 4. Alternative 2: "Community alternative," promoting social and community performance.

\subsubsection{Business as Usual: Preservation of the Previous Design}

This alternative aims to keep the main layout of the neighborhood as is; however, in this alternative, new buildings are incorporated into the open spaces using the infill practice, including increasing each building's height by two to four floors, keeping the buildings' floor shapes/sizes, and reducing and redefining the open public spaces between them. The height development is gradual: lower towards the outer parts, higher next to the street and on the other side of the street, and lower next to the public buildings (see Figure 5).

\section{Alternative 3}

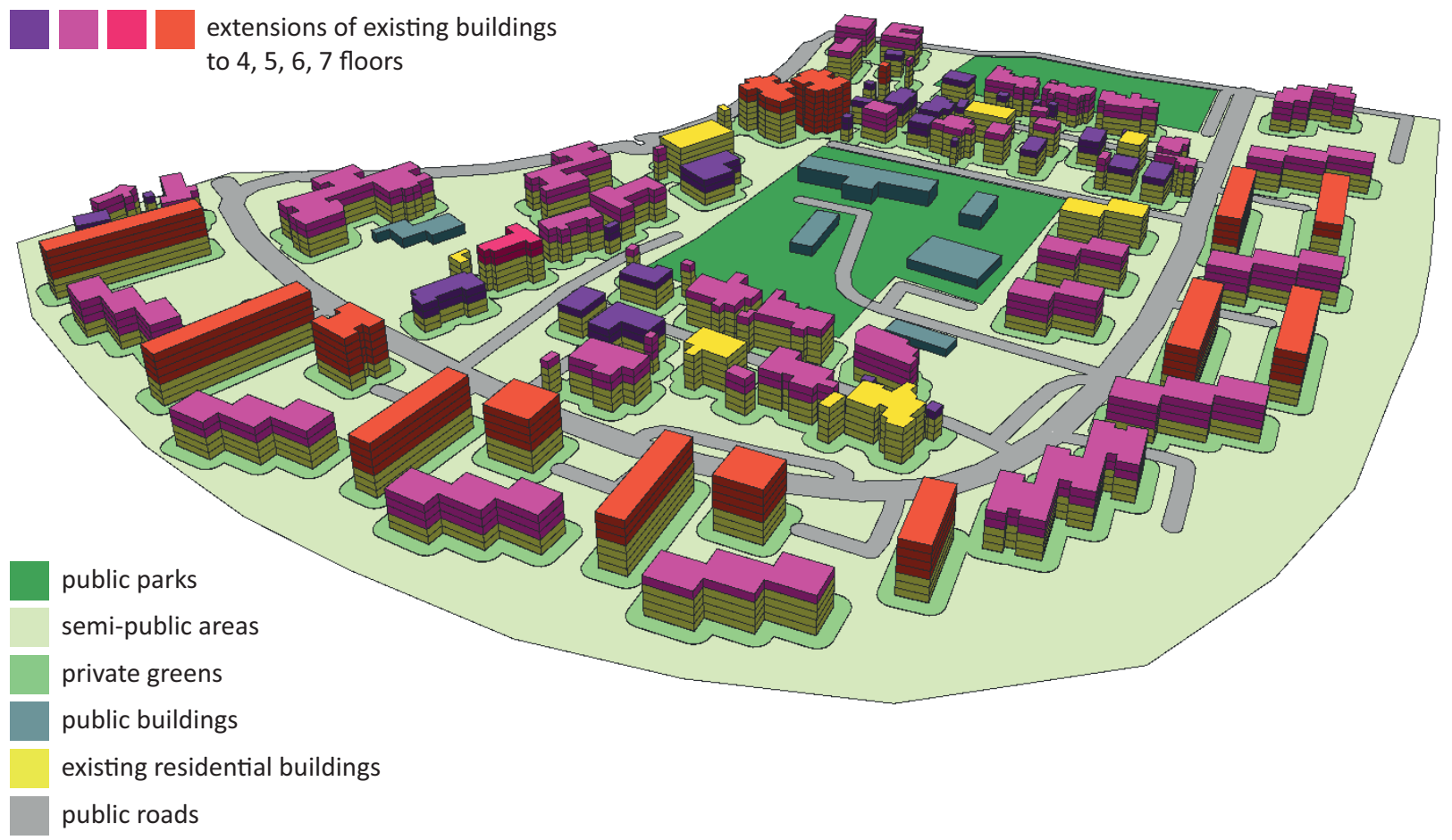

Figure 5. Alternative 3: "Business as usual" (preservation of previous design with additional floors). 


\subsection{Indicators}

To evaluate the quality and performance of these alternatives, we determined 15 measurable criteria, defined based on available data and evidence-based models, and tools for measuring the criteria. They are divided into two groups: basic indicators (Table 1, essential characteristics and key figures of the urban design) and performance indicators (Table 2, evaluating qualities of the design with regard to the ecological sustainability and quality of the environment criteria).

The analysis was developed in a small peripheral neighborhood of low-medium socioeconomic status. Most residents mainly travel within the neighborhood, using public facilities (schools, kindergartens, local commerce, etc.), carrying out errands mostly on foot. Designing the renewal of a neighborhood requires an understanding of how to measure several indicators: (a) Community resilience indices: green open areas, use of local energy, public transportation, surface runoff, and flood prevention, shade (vital for the hot Israeli climate); (b) walking through the neighborhood (walking paths) and walkability (independence from private vehicles); (c) personal sense of security; and (d) internal visibility (eyes on the street within the neighborhood) which contributes to security and a sense of community in the neighborhood. In this sense, walkability and walking quality within the neighborhood are important. However, walking out of the neighborhood towards the city remains the same for all alternatives; therefore,

Table 1. Basic indicators.

\begin{tabular}{lll}
\hline$\#$ & Quantitative Parameters and Indicators & Description \\
\hline 1 & Total Project area (in $\mathrm{m}^{2}$ ) & Total area including building plots, public roads, and public parks \\
& 1.1. Building plot area (in $\mathrm{m}^{2}$ ) & $\begin{array}{l}\text { Building Plot Area (1.1) = Total project area (1) - Roads (5) - Public green } \\
\text { spaces (4.3.) }\end{array}$
\end{tabular}

2 Building Footprints (in $\mathrm{m}^{2}$ )

3 Roof Area (in $\mathrm{m}^{2}$ )

3.1. Potential area for PV

4 Green Areas (in $\mathrm{m}^{2}$; potentially unsealed)

4.1. Private greens

4.2. Semi-public greens

4.3. Public greens

5 Paved (public) Roads (in $\mathrm{m}^{2}$; potentially sealed area)

6 Parking (in $\mathrm{m}^{2}$; potentially sealed area)

7 Sealed Area (in $\mathrm{m}^{2}$ )

8 8.1. Expected power demand (in kWh) 8.2. Compactness measure of building forms
Residential and public buildings footprint, housing units, gross-floorarea (GFA), and gross-floor-area ratio (GFAR, gross-floor-area/size of building plots).

Roof area is equated with the building footprint. Roofs can be used for green roofs and/or PV modules. We assumed that $70 \%$ of roof area can be used for these purposes.

Green Areas $=$ Total area (1) - roads (5) - building footprints (2) parking (6)

Private greens (4.1.) $=$ Courtyards $+5 \mathrm{~m}$ buffer around residential buildings

Semi-public greens (4.2.) = Building plots (1.1) - building footprints (2) private greens (4.1) - parking (6.)

Public greens (4.3.) $=$ Area of existing parks in $\mathrm{m}^{2}$

Street areas, not including private access roads and paths on building lots.

Resident parking: One lot $\left(25 \mathrm{~m}^{2}\right.$ according to Neufert \& Neufert, 1992/2009, p. 403, Table 12) per residential unit on building lots. Public parking: 0.5 lot/residential unit spreading along public roads.

Sealed areas $=$ Building footprints $(2)+$ Roads (5) + Parking spaces (6)

Expected Power demand (8.1.) = GFA (2.4) $\times$ average annual power demand/sqm: 93.5 kWh according to Hassid (2019, p. 42, Figure 3A). Reducing the surface area of a building envelope can help reduce energy consumption in the building and reduce the materials (and connected environmental impacts) used in the envelope's construction. The shape factor $\gamma=\frac{s}{s_{\min }}$ shows the surface-to-volume ratio of the buildings based on the concept of a compactness measure of sustainable building forms by D'Amico and Pomponi (2019). A value of 1 shows the "optimum" ratio of volume to surface. The GFA-weighted average of $y$ of the design is shown.

Note: General description and key values of urban designs. 
Table 2. Performance indicators.

Attribute Value Range

to Points

\begin{tabular}{l} 
Performance Indicator \\
\hline $9 \quad$ Public transport: Quality of service \\
The assessmentis based on the Austrian adaption (Schwillinsky et al., \\
2018) ofthe Swiss evaluation system of public transport quality (ARE, \\
2011). Attribute values of analysis method range from A (good) to G \\
(nonexistent public transport system), intervals, and timetables (Nateev \\
Express, n.d.).
\end{tabular}

10 Infiltration potential (IP)

IP is determined via the rainwater drainage and the respective runoff coefficients (DIN 1986-100:2016-12) ofthe surfaces using an adapted formula from German/European Standards DIN EN 12056-3 and DIN 1986-100, respectively Austrian Standard Ö-NORM B2501:2015. The indicator shows the extentto which a scenario achieves the optimal IP (complete unobstructed and unsealed surface) in the project area.

11 PV potential (on roofs) is calculated from solar radiation data provided by the Photovoltaic Geographical Information System (European Commission, 2019a, 2019b) and shown in percentage of energy consumption of expected inhabitants; it depends on the efficiency of PV modules (e.g., ENF Solar, n.d.; Photovoltaik.org, 2020) and available roof area.

Shaded areas are measured at noon hours ofthe average hottest days (15th July and 15th August at $11 \mathrm{am}$ and $4 \mathrm{pm}$ ) ofthe year. The size ofthe shaded areas is compared to the size ofthe project area minus the building footprints.

\section{Walkability}

The walkability index is measured by analyzing and integrating four parameters: building density, entropy index, mixed-use, and junction density, based on Feng et al. (2010) and Frank et al. (2010). The rates range from one (very low walkability) to five (very high walkability). The integrated walkability index is the percentage of cells/pixels with a high or very high walkability index.

$12+13$ The shade parameter will be added to the walkability index to understand the "quality walk" spatially and numerically.

\section{Sense of security}

The sense of security is measured using the SRI (Shach-Pinsly, 2019), a GIS-based model to identify secure and unsecured urban areas in a city. The system is based on measurements of urban elements that influence the sense of security in the built environment: mixed usage, building proximity, streetlights, the distance between junctions, and the number of intersections. The rates range from one (unsecured areas) to five (secured areas). The SRI is the percentage of cells/pixels with a high or very high secured index.

15 Visibility (eyes on the street, internal visibility) Internal visibility is measured by calculating all sightlines from each floor level toward the neighborhood open space, public and private, based on Shach-Pinsly, (2010), where the darker areas mark the most visible areas (5) and the lighter areas mark the less visible areas (1). The integrated internal visibility index is the percentage of cells/pixels with a high or very high internal visibility index.

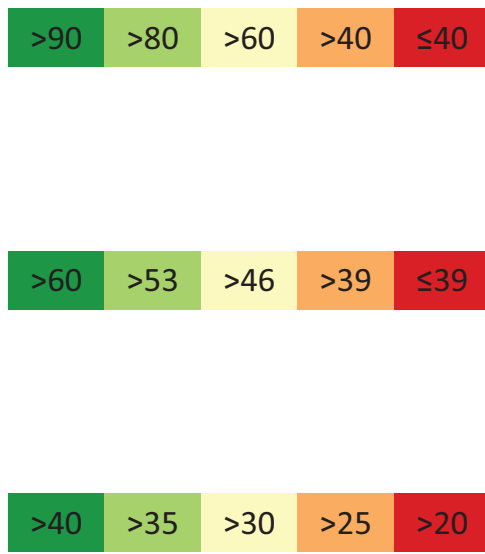

\begin{tabular}{|c|c|c|c|c|}
\hline$>60$ & $>53$ & $>46$ & >39 & $\leq 39$ \\
\hline$>40$ & $>35$ & $>30$ & $>25$ & $>20$ \\
\hline
\end{tabular}

$>40>35>30>25>20$


it was not included in the calculations. The methods and tools used for measuring the quality indicators (e.g., security, visibility) were based on validated tools.

In this research, we only measured internal visibility. We based the analysis on Shach-Pinsly (2010), where the internal visibility of a compound building area was measured. For the internal visibility analysis, we simulated windows in the three-dimensional façades (streetscape) facing the inner open spaces of the neighborhood. The outcome of this analysis shows that the public open areas are most visible from the building façades, and there is the possibility of "eyes on the street" in the neighborhood. Walking paths relate to the walking routes used by pedestrians to access different areas of the neighborhood. Walking paths enable better walking accessibility for pedestrians to diverse areas and usages in the neighborhood. In such residential neighborhoods, people mainly prefer to use the shortest walking path, and, in a hot climate such as Israel's, people prefer to walk on the shaded side of the walking paths/streets; both aspects are mainly influenced by the urban morphology, trees, etc.

The morphological typology of an area highly affects the performance and quality of the urban environment metrics. Therefore, the analysis was based on physical metrics for understanding the existing and renewed performance of the measured neighborhood for current and future residents. There are additional metrics that relate to residents' preferences in a neighborhood, usually drawn from questionnaires. However, the urban renewal alternatives intend to triple the neighborhood's population; thus, there are unknown residents whose opinions cannot yet be determined.

The tools for analyzing quality and performance aspects were validated in previous research: The sense of security analysis is based on the SRI tool that was developed and demonstrated in Shach-Pinsly (2019) and Shach-Pinsly and Ganor (2021) and was validated on the case studies of Tel-Aviv (Israel), Portland (US), and the Hadar neighborhood, Haifa, Israel. Furthermore, walkability analysis and validation were based on Feng et al. (2010) and Frank et al. (2010). Shade analysis is a widespread method for understanding the amount of shade in a particular place/area, as is shown in Rafiee et al. (2014) and in ESRI analysis tools. In order to estimate the energy consumption for the different designs, Granadeiro et al. (2013) and Depecker et al. (2001) have developed concepts that can be calculated using simulation software such as the US Department of Energy's EnergyPlus (US Department of Energy, 2021). In the work of Hassid (2019), the annual energy consumption per square meter. was determined for a reference building in the study region, which forms the simple basis for the extrapolation in our work. Currently, there are diverse visibility analysis methods and tools used for visibility evaluation. For this research, we based the internal visibility analysis on Shach-Pinsly (2010) since this study measures the internal visibility of a building compound or neighborhood.

\section{Results}

In the following section, Tables 3 and 4 show the respective indicators and key figures for the concrete variants described. The tables are followed by explanations of the selected indicators.

Further explanations and discussion on the results for Tables 3 and 4 follow:

Indicators 8 and 8.1: The estimated energy consumption is determined from average values and does not consider the structural implementation of the designs, household sizes, and user structure. The basis for calculating the expected energy consumption are the average values of the two simulations (ISO 13790, EnergyPlus) for the energy consumption for cooling and heating in $\mathrm{kWh} / \mathrm{m}^{2}$ of a reference building for the region around Hatzor HaGlilit carried out by Hassid (2019, p. 42, Figure 3A). However, the geometric analysis of the indicator 8.2-surface-tovolume ratio-provides a simple marker of the inherited efficiency of the design and indicates that the expected power demand will be higher, as calculated in 8.1. The reference building has got a $y=1.03$, which is close to the optimum of 1 .

Indicator 9: Quality of service of the designs does not vary much as designs do not change the location and available services (modes of transport, intervals, local and regional connections) at public transport stops.

Indicator 10: Whereas all design scenarios using the $\mathrm{BAU}$ variant $10 \mathrm{a}$ (water impermeable standard materials for roofs and parking) show poor performance, the more water-sensitive urban design variants (10b, c, and d) using grass pavers, green roofs, or both, reach up to $81 \%$ of the theoretical optimum $\left(Q_{\text {[umin] }}\right.$ runoff $859 \mathrm{l} / \mathrm{s}$ ) as illustrated in Figure 6a. The influence of green roofs on the balance of sealed and unsealed surfaces can be seen with the naked eye in Figures $6 \mathrm{~b}$ and $6 c$.

Indicator 11: The PV potential includes only the roof areas, as no investigations were carried out in the course of the study regarding the radiation of façades, materials, and the surroundings. Due to the low level of detail of the designs, potential areas for further PV installations (shading elements, façades) could not be considered in the calculations.

Regardless of the individual design, some indicators and characteristics have proven essential for high urban and ecological demands: Parking spaces account for a very high proportion of space in all variants, almost a quarter $(21 \%)$ of the total project area. The design of these areas offers considerable potential regarding avoidance of heat islands and improving IP. Parking garages should be implemented in the designs to reduce sealed areas as 
Table 3. Results: Basic indicators.

\begin{tabular}{|c|c|c|c|c|c|}
\hline \# & Basic Indicator & Existing Situation & Alternative 1 & Alternative 2 & Alternative 3 \\
\hline \multirow[t]{2}{*}{1} & Total Project Area (in $\mathrm{m}^{2}$ ) & 168,415 & 168,415 & 168,415 & 168,415 \\
\hline & 1.1. Building plot area (in $\mathrm{m}^{2}$ ) & 129,494 & 126,417 & 129,114 & 129,494 \\
\hline \multirow[t]{6}{*}{2} & Building Footprints (in $\mathrm{m}^{2}$ ) & 25,313 & 31,861 & 35,644 & 25,313 \\
\hline & 2.1. Residential buildings footprint & 22,886 & 29,434 & 33,217 & 22,886 \\
\hline & 2.2. Housing units & 900 & 1,425 & 1,425 & 1,425 \\
\hline & 2.3. Public buildings footprint & 2,427 & 2,427 & 2,427 & 2,427 \\
\hline & 2.4. GFA & 73,755 & 141,588 & 187,013 & 129,522 \\
\hline & 2.5. GFAR & 0.49 & 1.12 & 1.45 & 1.00 \\
\hline \multirow[t]{2}{*}{3} & Roof Area (in $\mathrm{m}^{2}$ ) & 22,886 & 29,434 & 33,217 & 22,886 \\
\hline & 3.1. Potential area for PV & 16,020 & 20,604 & 23,252 & 16,020 \\
\hline \multirow[t]{4}{*}{4} & Green Areas (in $\mathrm{m}^{2}$; unsealed area) & 86,335 & 79,742 & 78,490 & 86,335 \\
\hline & 4.1. Private greens & 34,858 & 27,539 & 30,065 & 34,858 \\
\hline & 4.2. Semi-public greens & 46,823 & 31,391 & 27,780 & 33,698 \\
\hline & 4.3. Public greens & 17,779 & 20,811 & 20,644 & 17,779 \\
\hline 5 & Paved (public) roads (in $\mathrm{m}^{2}$; sealed area) & 21,179 & 21,224 & 18,693 & 21,179 \\
\hline 6 & Parking (in $\mathrm{m}^{2}$; sealed area) & 22,500 & 35,625 & 35,625 & 35,625 \\
\hline 7 & Sealed area (in $\mathrm{m}^{2}$ ) & 68,992 & 88,710 & 89,962 & 82,117 \\
\hline \multirow[t]{2}{*}{8} & 8.1. Expected power demand (in kWh) & $6,896,093$ & $12,485,055$ & $16,732,269$ & $11,356,842$ \\
\hline & 8.2. Compactness measure $y$ & 1.247 & 1.249 & 1.202 & 1.304 \\
\hline
\end{tabular}

Note: Differences between the building plot area sizes in the scenarios arise from the fact that the properties are connected differently by public roads.

Table 4. Results: Performance indicators of design alternatives.

\begin{tabular}{|c|c|c|c|c|c|}
\hline \# & Performance Indicator & Existing Situation & Alternative 1 & Alternative 2 & Alternative 3 \\
\hline 9 & Public transport: Quality of service & $\mathrm{D}$ & D & $\mathrm{D}$ & $\mathrm{D}$ \\
\hline $\begin{array}{l}10 \\
a\end{array}$ & $\begin{array}{l}\text { IP business as usual (BAU): Rain runoff/ } \\
\text { drainage }(\mathrm{Q}) \text { in liters/second }(\mathrm{I} / \mathrm{s} \text { ) on the } \\
\text { project area (\% of optimum) }\end{array}$ & $\begin{array}{l}3,777 \mathrm{l} / \mathrm{s} \\
(58 \%)\end{array}$ & $\begin{array}{l}4,366 \mathrm{l} / \mathrm{s} \\
(50 \%)\end{array}$ & $\begin{array}{l}4,551 \mathrm{l} / \mathrm{s} \\
(47 \%)\end{array}$ & $\begin{array}{c}4,083 \mathrm{l} / \mathrm{s} \\
(54 \%)\end{array}$ \\
\hline b & $\begin{array}{l}\text { Q Parking: Grass pavers with frequent traffic } \\
\text { loads (e.g., parking lots; \% of optimum) }\end{array}$ & $\begin{array}{l}2,727 \mathrm{l} / \mathrm{s} \\
(73 \%)\end{array}$ & $\begin{array}{l}2,703 \mathrm{l} / \mathrm{s} \\
(74 \%)\end{array}$ & $\begin{array}{c}2,889 \mathrm{l} / \mathrm{s} \\
(71 \%)\end{array}$ & $\begin{array}{l}2,421 \mathrm{l} / \mathrm{s} \\
(78 \%)\end{array}$ \\
\hline c & $\begin{array}{l}\text { Q Green Roofs: Extensive greening, from } \\
10 \mathrm{~cm} \text { build-up thickness ( } \leq 5^{\circ} ; \% \text { of optimum) }\end{array}$ & $\begin{array}{l}2,709 \mathrm{l} / \mathrm{s} \\
(74 \%)\end{array}$ & $\begin{array}{l}2,992 \mathrm{l} / \mathrm{s} \\
(70 \%)\end{array}$ & $\begin{array}{l}3,001 \mathrm{l} / \mathrm{s} \\
(69 \%)\end{array}$ & $\begin{array}{l}3,015 \mathrm{l} / \mathrm{s} \\
(69 \%)\end{array}$ \\
\hline d & $\begin{array}{l}\text { Q Parking and Green Roofs: Parking and Green } \\
\text { Roof variants combined (\% of optimum) }\end{array}$ & $\begin{array}{c}1,659 \mathrm{l} / \mathrm{s} \\
(89 \%)\end{array}$ & $\begin{array}{c}1,330 \mathrm{l} / \mathrm{s} \\
(93 \%)\end{array}$ & $\begin{array}{c}1,339 \mathrm{l} / \mathrm{s} \\
(93 \%)\end{array}$ & $\begin{array}{c}1,353 \mathrm{l} / \mathrm{s} \\
(93 \%)\end{array}$ \\
\hline 11 & $\begin{array}{l}\text { PV potential (in kWh; \% of assumed total } \\
\text { energy consumption in 8.1.) }\end{array}$ & $\begin{array}{l}4,994,377 \\
(72 \%)\end{array}$ & $\begin{array}{l}6,422,501 \\
(51 \%)\end{array}$ & $\begin{array}{l}7,248,136 \\
(43 \%)\end{array}$ & $\begin{array}{l}4,994,377 \\
(44 \%)\end{array}$ \\
\hline 12 & $\begin{array}{l}\text { Shaded area }\left(\mathrm{m}^{2}\right) \\
\text { Shaded area }(\%)\end{array}$ & $\begin{array}{c}31,533 \\
19 \%\end{array}$ & $\begin{array}{c}70,634 \\
42 \%\end{array}$ & $\begin{array}{c}76,200 \\
46 \%\end{array}$ & $\begin{array}{c}56,787 \\
34 \%\end{array}$ \\
\hline 13 & $\begin{array}{l}\text { Area of walking paths }\left(\mathrm{m}^{2}\right) \\
\text { Area of walking paths (\%) } \\
\text { Relative walkability score (based on Feng } \\
\text { et al., 2010; Frank et al., 2010) }\end{array}$ & $\begin{array}{c}65,916 \\
39 \% \\
0.69\end{array}$ & $\begin{array}{c}58,572 \\
35 \% \\
0.7\end{array}$ & $\begin{array}{c}49,392 \\
29 \% \\
-1.39\end{array}$ & $\begin{array}{c}65,916 \\
39 \% \\
0.69\end{array}$ \\
\hline $12+13$ & Area of shaded walking paths (\%) & $13 \%$ & $25 \%$ & $32 \%$ & $14 \%$ \\
\hline 14 & Sense of security & $46 \%$ & $22 \%$ & $29 \%$ & $46 \%$ \\
\hline 15 & Visibility (internal visibility, eyes on the street) & $11 \%$ & $48 \%$ & $44 \%$ & $39 \%$ \\
\hline
\end{tabular}




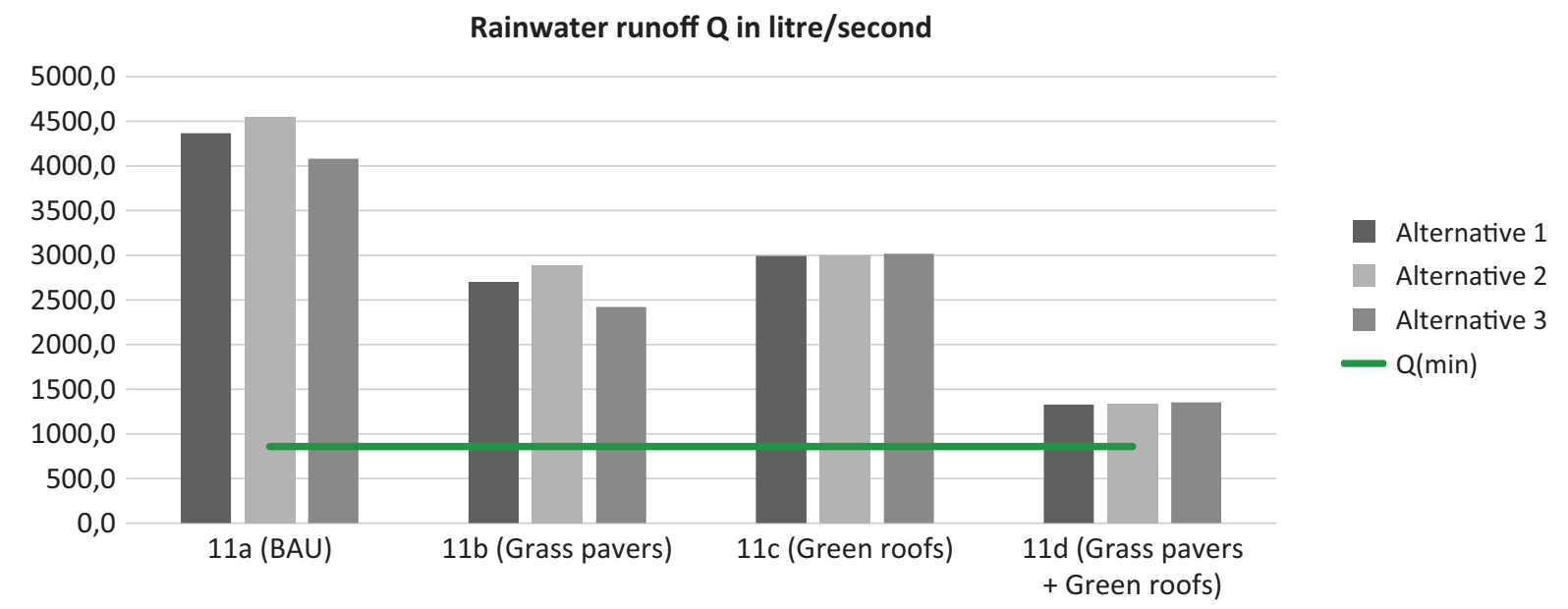

(a) Total rainwater runoff $Q$ for design scenarios and variants in project area.

Alternative 3a - Sealed surfaces

runoff coefficient $1,0.3,0.2,0.15$

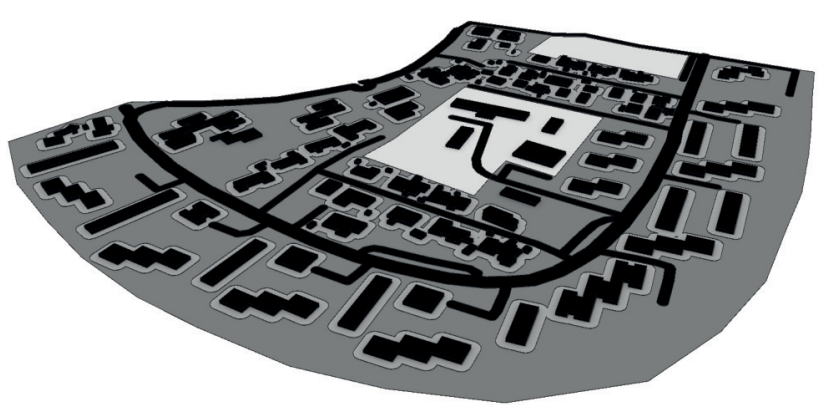

(b) Alternative 3a (BAU).
Alternative 3c - Green roofs

runoff coefficient $1,0.3,0.2,0.15$

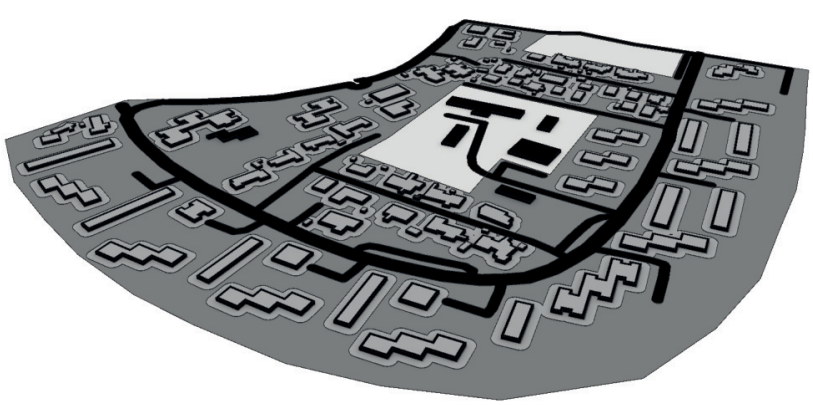

(c) Alternative 3c (Green Roofs).

Figure 6. Total rainwater runoff for design scenarios and variants in project area (a) and exemplary graphic display of IP of sealed and unsealed areas of Alternative 3 as BAU (b) or with green roofs (c).

it has a great influence on water-sensitive urban design (performance indicator 11; see comparison of variants $11 \mathrm{a}$ to $11 \mathrm{~d}$ ). Figure 7 demonstrates the spatial analysis for indicators 12 (shadow), 14 (sense of security), and 15 (internal visibility, eyes on the street) for all alternatives.

The spatial analysis in Figure 7 shows the different layouts of the indicator outcomes over the alternatives. The analysis shows similarities between several hot spots of the internal visibility and the security analysis. For example, in Alternative 1, at the eastern-lower part and the eastern-northern part of the plan, there are safer areas with relatively easily walkable areas and a walking path with shadows (see Table 4). In this research, we measured shade from the buildings; however, additional vegetation should be added and has the potential to increase the shaded area for walking and as a whole.

\section{Conclusions}

The neighborhood renewal process is an opportunity to increase the performance and quality of the urban environment for its present and future residents and for urban functionality. The neighborhood renewal pro- cess can also threaten the neighborhood's quality, gentrification, social separation, and community segregation. There is much to gain and much to lose in the process of neighborhood renewal. To increase opportunities and decrease threats, planners and decision-makers need to act and design according to values, available data, and indicators. They should understand the quality of the environment, the existing or developed neighborhood, and its influence on urban performance for the benefit of the community.

The performance-based codes (Shach-Pinsly \& Capeluto, 2020) aim to integrate performance analysis into the planning and design process. In this research, we demonstrated this line of analysis in one neighborhood based on several selected indicators. We analyzed the spatial performance of an existing neighborhood, as well as three urban renewal alternatives. Our analysis focused on the performance measures, walkability, public transportation, IP, solar potential, sense of security, shade, and internal visibility. This range of spatial quality performance indicators could assist planners and decision-makers in assessing and estimating neighborhood renewal alternatives. 


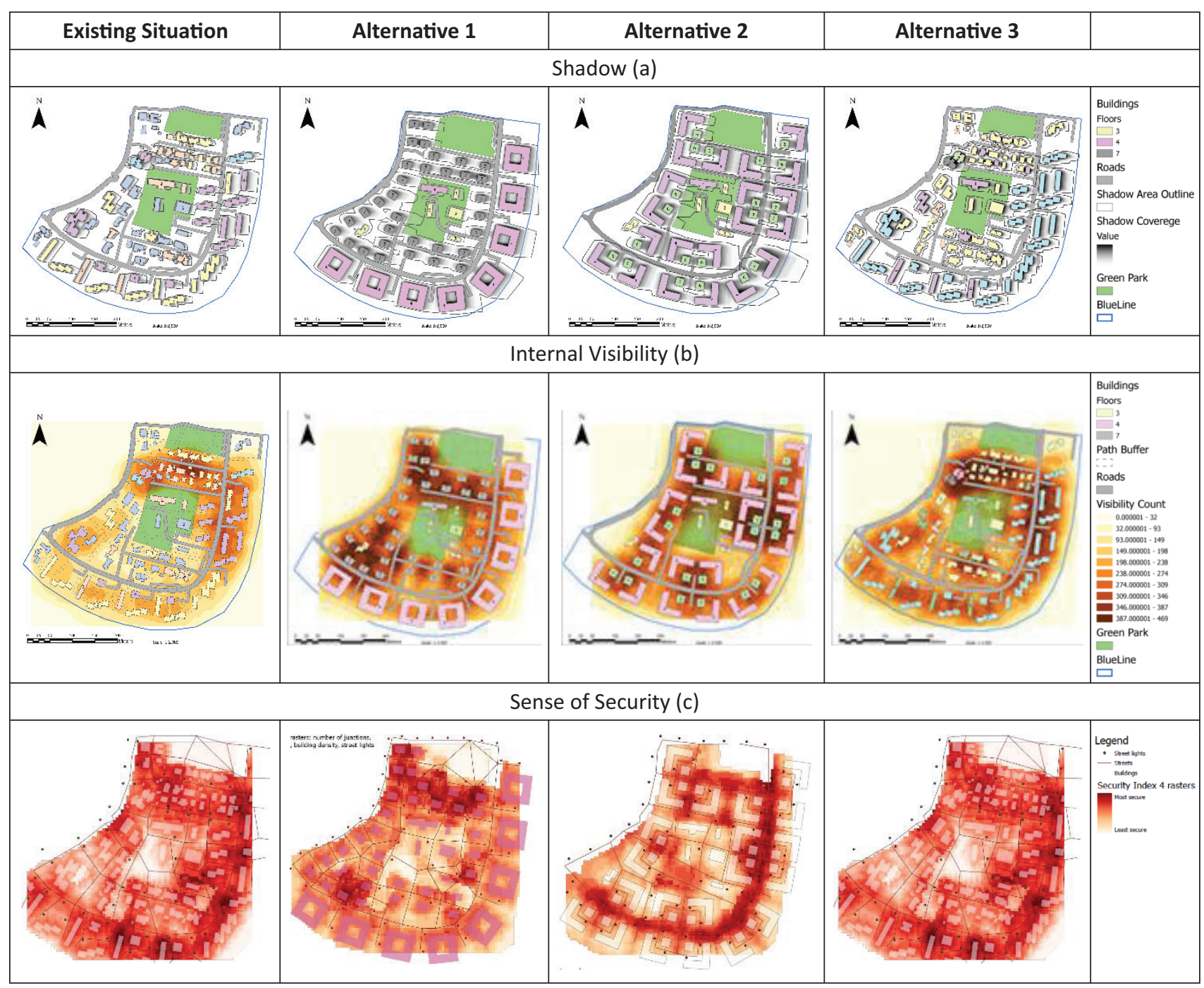

Figure 7. Noon hours of the average hottest days (15th July and 15th August, 11 am and 4 pm): (a) shadow analysis, (b) Internal visibility (eyes on the street); and (c) sense of security based on the SRI (Shach-Pinsly, 2019).

Through the analysis in this article, we calculated and showed the spatial quality differences in a range of neighborhood design alternatives. Results, focused mainly on inner open public residential areas, show that the area of shaded walking paths increased by $19 \%$ and internal visibility by $37 \%$. Although the most secured areas relatively decreased by $24 \%$ and remained the same as Alternative 3, these areas were more focused in inner residential areas, and large areas of the renewed alternatives show medium levels of sense of security. The IP decreased down to minus $11 \%$ but can be optimized (up to more $40 \%$ ) in all designs by choosing waterpermeable surfaces. The higher energy demand of more housing units reduces the relative PV potential (down to minus $29 \%$ ). Other indices remain with no significant change. The differences between alternatives and the original state may be considered as differences in the quality of the scenarios.

Since the applied tools have been validated in previous research, we can rely on these validations. Based on this authentication, we developed the comparative eval- uation for establishing the decision-making/evaluation process. Interestingly, we found a correlation, for example, between visibility analysis and security analysis. Currently, the planning system in general, and urban characteristics in particular, lack tools for evaluating quality and performance parameters; therefore, here lies the importance of this research and the need to develop a performance analysis framework as a basis for decisionmaking. Based on the analysis results, inherent weaknesses and strengths of the urban renewal designs can be identified and addressed at an early planning stage and serve as basic data for planning decision making when estimating future neighborhood regeneration performance and its effect on the society and community. It is important to note that there is no "perfect" or "optimal" neighborhood design; rather, there are different alternatives with a range of qualities to estimate.

The method used is suitable for the rapid assessment and comparative evaluation of design alternatives. The multiparametric analysis allows one to understand the relationship between the different qualities and 
better understand the performance of the built environment. Currently, many evaluation models offer a numerical index without a spatial layout. Integrating numerical indexes and spatial indexes allows one to better suit the morphology design of the neighborhood, resulting in higher levels of quality and performance. For example, designing shaded and secured walkways located in diverse neighborhood locations based on multiparametric analysis allows residents to enjoy quality walkability while enabling better solar potential and green roofs by changing the morphology design.

Overall, the presented method shows the potential of spatial design-based knowledge analysis and decision support, as it can be used to investigate essential aspects (such as walkability, soil sealing and water-sensitive urban design, shading, energy potential, etc.), independent of the design variant. If these aspects are considered at an early stage in a design, they can be set as criteria in tendering procedures and competitions, thus ensuring that all design variants achieve higher quality.

\section{Acknowledgments}

This publication is based upon work from COST Action, European Middle Class Mass Housing (MCMH-EU) CA 18137 supported by COST (European Cooperation in Science and Technology). www.cost.eu

\section{Conflict of Interests}

The authors declare no conflict of interests.

\section{References}

Apparicio, P., Séguin, A. M., \& Naud, D. (2008). The quality of the urban environment around public housing buildings in Montréal: An objective approach based on GIS and multivariate statistical analysis. Social Indicators Research, 86(3), 355-380.

ARE. (2011). ÖV-Güteklassen: Berechnungsmethodik. ARE. Grundlagenbericht für die Beurteilung der Agglomerationsprogramme Verkehr und Siedlung [Public transport quality classes: Calculation methodology. Federal Office for Spatial Development. Basic report for the assessment of agglomeration programs transport and settlement]. https://www.are. admin.ch/are/de/home/medien-undpublikationen/publikationen/verkehr/ovguteklassen-berechnungsmethodik-are.html

Bain, L., Gray, B., \& Rodgers, D. (2012). Living streets: Strategies for crafting public space. Wiley.

Bibri, S. E., Krogstie, J., \& Kärrholm, M. (2020). Compact city planning and development: Emerging practices and strategies for achieving the goals of sustainable development. Developments in the Built Environment, 4, Article 100021. https://doi.org/10.1016/ j.dibe.2020.100021

Carmon, N. (1998). Immigrants as carriers of urban regen- eration: International evidence and an Israeli case study. International Planning Studies, 3(2), 207-225.

Carmon, N. (2001). Housing policy in Israel: Review, evaluation and lessons. Israel Affairs, 7(4), 181-208.

Carmona, M. (2019). Place value: Place quality and its impact on health, social, economic and environmental outcomes. Journal of Urban Design, 24(1), 1-48.

Carmona, M., \& Magalhães, C. (2007). Local environmental quality: A new view on measurement. Communities and Local Government Publications.

Carmona, M., \& Sieh, L. (2004). Measuring quality in planning: Managing the performance process. Routledge.

Cervero, R., \& Kockelman, K. (1997). Travel demand and the 3Ds: Density, diversity, and design. Transportation Research Part D: Transport and Environment, 2(3), 199-219.

Cicerchia, A. (1996). Indicators for the measurement of the quality of urban life. Social Indicators Research, 39(3), 321-358.

Cruz, L., \& Abreu, R. (2017). Performance-based guidelines for energy efficient mobile applications. In 2017 IEEE/ACM 4th International Conference on Mobile Software Engineering and Systems (MOBILESoft) (pp. 46-57). IEEE/ACM.

Cunningham, M. K., \& Sawyer, N. (2005). Moving to better neighborhoods with mobility counseling (Brief No. 8). Metropolitan Housing and Communities Center.

D’Amico, B., \& Pomponi, F. (2019). A compactness measure of sustainable building forms. Royal Society Open Science, 6(6), Article 181265. https://doi.org/ 10.1098/rsos.181265

D’Ignazio, C., \& Klein, L. F. (2020). Data feminism. MIT Press.

Depecker, P., Menezo, C., Virgone, J., \& Lepers, S. (2001). Design of buildings shape and energetic consumption. Building and Environment, 36(5), 627-635. https://doi.org/10.1016/s0360-1323(00)00044-5

Duinker, P. N., \& Greig, L. A. (2007). Scenario analysis in environmental impact assessment: Improving explorations of the future. Environmental Impact Assessment Review, 27(3), 206-219.

ENF Solar. (n.d.). VSUN320-60M. https://de.enfsolar. $\mathrm{com} / \mathrm{pv} /$ panel-datasheet/crystalline/43194

European Commission. (2019a). JRC Photovoltaic Geographical Information System (PVGIS): Performance of grid-connected PV. Photovoltaic Geographical Information System. https://re.jrc.ec.europa.eu/ pvg_tools/en/\#PVP

European Commission. (2019b). JRC Photovoltaic Geographical Information System (PVGIS): Typical meteorological year. Photovoltaic Geographical Information System. https://re.jrc.ec.europa.eu/pvg_tools/ es/\#TMY

Ewing, R. H., \& Clemente, O. (2013). Measuring urban design: Metrics for livable places. Island Press.

Feng, J., Glass, T. A., Curriero, F. C., Stewart, W. F., \& Schwartz, B. S. (2010). The built environment and 
obesity: A systematic review of the epidemiologic evidence. Health \& Place, 16, 175-190.

Fitzgibbons, J., \& Mitchell, C. (2019). Just urban futures? Exploring equity in "100 resilient cities." World Development, 122, 648-659.

Florida, R. (2014). Walkability is good for you. Bloomberg CityLab. https://www.bloomberg.com/news/ articles/2014-12-11/walkability-is-good-for-you

Foliente, G. C. (2000). Developments in performancebased building codes and standards. Forest Products Journal, 50(7/8), 12-21.

Forster, J. (2016). Strategische raumbezogene Visualisierung im Kontext der Innenentwicklung urbaner Siedlungs-, Energie- und Mobilitätssysteme am Beispiel der Stadt Wien [Strategic spatial visualization in the context of the inner development of urban settlement, energy, and mobility systems using the example of the city of Vienna] [Doctoral dissertation, Vienna University of Technology]. reposiTUm. https://repositum.tuwien.at/handle/20.500.12708/ 4792

Frank, L. D., Sallis, J. F., Saelens, B. E., Leary, L., Cain, K., Conway, T. L., \& Hess, P. M. (2010). The development of a walkability index: Application to the neighborhood quality of life study. British Journal of Sports Medicine, 44(13), 924-933.

Gaffron, P., Huismans, G., \& Skala, F. (Eds.). (2005). Ecocity. Book 1: A better place to live. Facultas Verlagsund Buchhandels AG.

Goetz, E. G. (2010). Desegregation in 3D: Displacement, dispersal and development in American public housing. Housing Studies, 25(2), 137-158.

Granadeiro, V., Correia, J. R., Leal, V. M. S., \& Duarte, J. P. (2013). Envelope-related energy demand: A design indicator of energy performance for residential buildings in early design stages. Energy and Buildings, 61, 215-223. https://doi.org/10.1016/j.enbuild. 2013.02 .018

Hassid, S. (2019). EnergyPlus vs. Monthly ISO 13790 for Israeli climatic zones. Athens Journal of Sciences, 6(1), 35-60. https://doi.org/10.30958/ajs.6-1-3

Healey, P. (1995). The institutional challenge for sustainable urban regeneration. Cities, 12(4), 221-230.

Huber, F. J. (2011). Sensitive urban renewal or gentrification? The case of the Karmeliterviertel in Vienna. In C. Perrone, G. Manella, \& L. Tripodi (Eds.), Everyday life in the segmented city (pp. 223-239). Emerald Publishing.

Hui, S. C. M. (2002, July 8-10). Using performancebased approach in building energy standards and codes [Conference paper]. Chongqing-Hong Kong Joint Symposium 2002, Chongqing, China.

Jeffry, P., \& Pounder, J. (2016). Chapter 5: Physical and environmental aspects. In P. Roberts, H. Sykes, \& R. Granger (Eds.), Urban regeneration (pp. 87-98). SAGE.

Kleinhans, R. (2004). Social implications of housing diversification in urban renewal: A review of recent liter- ature. Journal of Housing and the Built Environment, 19(4), 367-390.

Leslie, E., Coffee, N., Frank, L., Owen, N., Bauman, A., \& Hugo, G. (2007). Walkability of local communities: Using geographic information systems to objectively assess relevant environmental attributes. Health \& Place, 13(1), 111-122.

Mitteregger, M., Bruck, E., Soteropoulos, A., Stickler, A., Berger, M., Dangschat Jens, S., \& Scheuvens, R. (2019). AVENUE21. Autonomer Verkehr: Entwicklungen des urbanen Europa [AVENUE21. Autonomous transport: Developments in urban Europe]. TU Wien Academic Press.

Mumford, L. (1954). The neighborhood and the neighborhood unit. The Town Planning Review, 24(4), 256-270.

Nateev Express. (n.d.). Homepage. http://www.nateev express.com

Neufert, E., \& Neufert, P. (2009). Bauentwurfslehre: Grundlagen, Normen, Vorschriften über Anlage, Bau, Gestaltung, Raumbedarf, Raumbeziehungen, Masse für Gebäude, Räume, Einrichtungen, Geräte mit dem Menschen als Mass und Ziel. Handbuch für den Baufachmann, Bauherrn, Lehrenden und Lernenden [Building design: Fundamentals, standards, regulations on construction, design, space requirements, spatial relationships, dimensions for buildings, rooms, facilities, equipment for people. Manual for the building professional, builder, teacher, and learner] (39th ed.). Vieweg. (Original work published 1992)

Ortner, T., Sorger, J., Steinlechner, H., Hesina, G., Piringer, H., \& Gröller, E. (2016). Vis-a-ware: Integrating spatial and non-spatial visualization for visibility-aware urban planning. IEEE Transactions On Visualization And Computer Graphics, 23(2), 1139-1151.

Papas, M. A., Alberg, A. J., Ewing, R., Helzlsouer, K. J., Gary, T. L., \& Klassen, A. C. (2007). The built environment and obesity. Epidemiologic Reviews, 29(1), 129-143.

Perry, C. (2007). The neighborhood unit. In M. Larice \& E. Macdonald (Eds.), The urban design reader (pp. 54-65). Routledge.

Photovoltaik.org. (2020). Photovoltaik Wirkungsgrad [Efficiency of PV modules]. https://www. photovoltaik.org/wissen/photovoltaik-wirkungsgrad

Planning Director. (2005). National outline plan for strengthening existing buildings against earthquakes. https://www.gov.il/he/departments/general/ tama_38

Porat, I., \& Shach-Pinsly, D. (2019). Building morphometric analysis as a tool for urban renewal: Identifying post-Second World War mass public housing development potential. Environment and Planning B: Urban Analytics and City Science, 48(2), 248-264. https:// doi.org/10.1177/2399808319861977

Rafiee, A., Dias, E., Fruijtier, S., \& Scholten, H. (2014). From BIM to geo-analysis: View coverage and 
shadow analysis by BIM/GIS integration. Procedia Environmental Sciences, 22, 397-402.

Schönwandt, W. (1999). Grundriss einer Planungstheorie der "dritten Generation" [Outline of a "third generation" planning theory]. DisP-The Planning Review, 35(136/137), 25-35. https://doi.org/ 10.1080/02513625.1999.10556696

Schwillinsky, S., Weiss, L., \& Herbst, S. (2018). ÖVGüteklassen: ein Werkzeug zur Analyse der Versorgung eines Standortes mit ÖV [PT service quality levels: A tool for the location-based analysis of public transport (PT) supply]. AGIT-Journal Fur Angewandte Geoinformatik, 4, 212-217. https://doi.org/ $10.14627 / 537647027$

Selle, K. (1997). Planung und Kommunikation [Planning and communication]. DisP-The Planning Review, 129, 40-47.

Shach-Pinsly, D. (2010). Visual exposure and visual openness analysis model used as evaluation tool during the urban design development process. Journal of Urbanism, 3(2), 161-184.

Shach-Pinsly, D. (2019). Measuring security in the built environment: Evaluating urban vulnerability in a human-scale urban form. Landscape and Urban Planning, 191, Article 103412.

Shach-Pinsly, D., \& Capeluto, I. G. (2020). From formbased to performance-based codes. Sustainability, 12(14), Article 5657. https://doi.org/10.3390/ su12145657

Shach-Pinsly, D., \& Ganor, T. (2021). A new approach for assessing secure and vulnerable areas in central urban neighborhoods based on social-groups' analysis. Sustainability, 13(3), Article 1174.

Shach-Pinsly, D., \& Porat, I. (2016). Multi-identity planning process in a studio course: Integrative planning in multi-identity environments. Frontiers of Architectural Research, 5(3), 279-289.

Shadar, H. (2009). Cultural questions of public housing.
Bezalel Publication.

Shadar, H., Orr, Z., \& Maizel, Y. (2011). Contested homes professionalism, hegemony, and architecture in times of change. Space and Culture, 14(3), 269-290.

Sharifi, A., \& Murayama, A. (2013). A critical review of seven selected neighborhood sustainability assessment tools. Environmental Impact Assessment Review, 38, 73-87.

Shelton, T. (2008). Visualizing sustainability in urban conditions. WIT Transactions on Ecology and the Environment, 113, 253-262.

Szibbo, N. A. (2015). Livability and LEED-ND: The challenges and successes of sustainable neighborhood rating systems [Doctoral dissertation, University of California, Berkeley]. eScholarship. https:// escholarship.org/uc/item/48k1c29c

Talen, E. (1996). After the plans: Methods to evaluate the implementation success of plans. Journal of Planning Education and Research, 16(2), 79-91.

Tavares, R. M. (2009). An analysis of the fire safety codes in Brazil: Is the performance-based approach the best practice? Fire Safety Journal, 44(5), 749-755.

The Israeli Green Building Council. (n.d.). Neighborhood $360^{\circ}$. http://www.nd360.org

Ulpan 2. (2019). A studio course: The development of a master-plan, the case of Hatzor HaGlilit. Faculty of Architecture and Town building, Technion-IIT.

US Department of Energy. (2021). EnergyPlus. https:// energyplus.net

Waddel, P. (2002). UrbanSim: Modeling urban development for land use, transportation, and environmental planning. Journal of the American Planning Association, 68(3), 297-314.

Waldner, L. S. (2004). Planning to perform: Evaluation models for city planners. Berkeley Planning Journal, 17(1). https://doi.org/10.5070/bp317111510

\section{About the Authors}
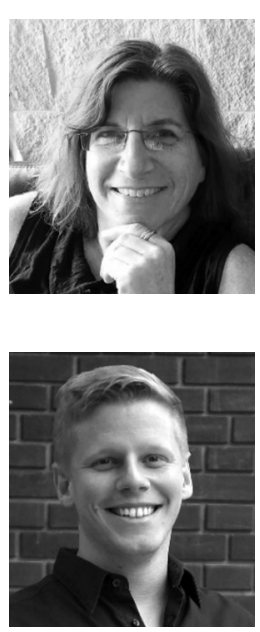

Dalit Shach-Pinsly, PhD, is an architect and urban designer. She is currently a researcher and senior lecturer at the Technion-IIT. She was a partner investigator in the H2020-MG-9.2-2014 MIND-SETSMobility Innovations for a New Dawn in Sustainable Transport Systems. She was a senior researcher of FP7-DESURBS-EU-Designing Safer Urban Spaces. Formerly she joined the College of Built Environments at the University of Washington as a post-doctoral fellow sponsored by the competitive Marie Curie EU IOF Fellowship (2008-2011).

Stefan Bindreiter is a spatial planner and software developer and holds an MSc in Spatial Planning from the Vienna University of Technology and an MSc in Digital Media from the University of Applied Sciences in Hagenberg. He is a PhD student and project researcher at Vienna University of Technology's Spatial Simulation Lab with a research focus on algorithm-based analysis tools for spatial planning. He addresses the concrete application of these methodologies in the creation and implementation of macro-regional planning strategies. 


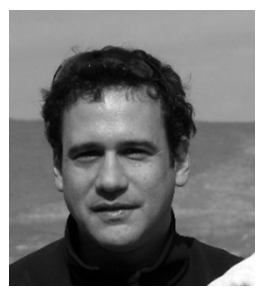

Idan Porat, PhD, holds a BA in Environmental Studies, an MSc, and a PhD (with excellence) in Urban And Regional Planning from the Technion-Israel Institute of Technology. He is an associate teaching fellow and senior researcher at the Technion-Israel Institute of Technology. He is one of the founders of the Spatial Capital Lab and the Spatial Planning \& Design Lab at the Center for Urban and Regional Studies and the leading researcher of the "Israel 100" national strategic plan.

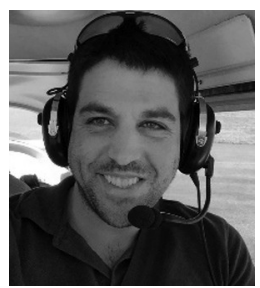

Shai Sussman is a civil engineer in Geoinformation and has recently completed a Master's in Urban Planning at the Technion-Israel Institute of Technology under the supervision of Dr. Meirav Aharon Gutman. As part of his thesis, he was involved in a joint venture between Cornell-Tech and the Technion, where he developed a time-based spatial-microsimulation platform to simulate demographic behavior in an urban renewal context.

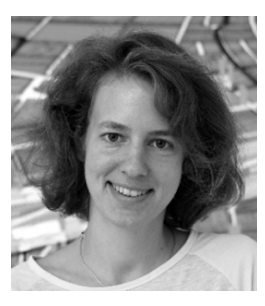

Julia Forster, PhD, is a senior scientist and head of the Spatial Simulation Lab (Simlab) at the Vienna University of Technology. She is a trained architect and holds a PhD in Spatial Planning, for which she was awarded the Ressel Prize of Vienna University of Technology. She is concerned with strategic visualization of energy and mobility data in settlement areas as a tool to support planning and decisionmaking. Her research focuses on digital spatial visualization for holistic system views and agile collaboration among domain experts.

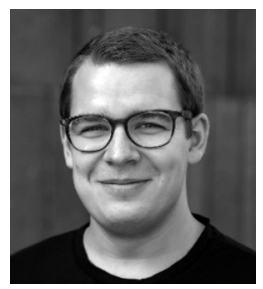

Michael Rinnerthaler is a spatial planner and holds a BSc and an MSc in Spatial Planning from Vienna University of Technology. He was a project researcher at Vienna University of Technology's Spatial Simulation Lab. 